This is a self-archived version of an original article. This version may differ from the original in pagination and typographic details.

Author(s): Roiha, Anssi; Sommier, Mélodine

Title: Viewing CLIL through the eyes of former pupils : Insights into foreign language and intercultural attitudes

Year: 2018

Version: Accepted version (Final draft)

Copyright: @ 2018 Informa UK Limited, trading as Taylor \& Francis Group

Rights: In Copyright

Rights url: http://rightsstatements.org/page//nC/1.0/?language=en

Please cite the original version:

Roiha, A., \& Sommier, M. (2018). Viewing CLIL through the eyes of former pupils : Insights into foreign language and intercultural attitudes. Language and Intercultural Communication, 18(6), 631-647. https://doi.org/10.1080/14708477.2018.1465069 


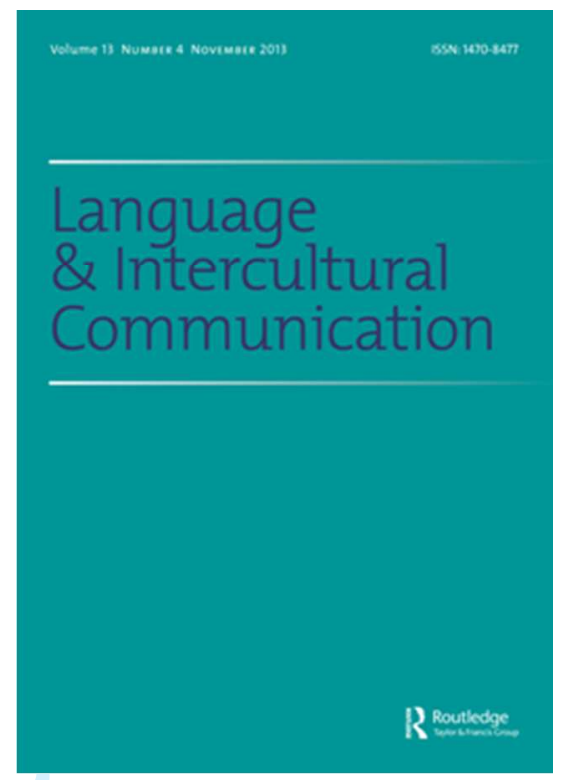

\section{Viewing CLIL through the eyes of former pupils: Insights into foreign language and intercultural attitudes}

\begin{tabular}{|r|l|}
\hline Journal: & Language and Intercultural Communication \\
\hline Manuscript ID & LAIC-1156.R2 \\
\hline Manuscript Type: & Paper \\
\hline Keywords: & CLIL, foreign language attitudes, intercultural attitudes, education, Finland \\
\hline Abstract: & $\begin{array}{l}\text { This article examines the long-term effects of CLIL on former pupils' } \\
\text { foreign language and intercultural attitudes. The 24 participants, who } \\
\text { received English-medium CLIL for nine years in the 1990s, were } \\
\text { interviewed and the data analyzed using thematic analysis. The } \\
\text { participants generally felt that CLIL had had a very positive effect on their } \\
\text { target language attitudes. However, many considered that CLIL had } \\
\text { affected negatively on their attitudes towards other foreign languages. The } \\
\text { perceptions regarding the effect of CLIL on intercultural attitudes diverged } \\
\text { more. The study elucidates the long-standing impact CLIL can have on } \\
\text { individuals' attitudes yielding insights into future CLIL education. }\end{array}$ \\
\hline \multicolumn{2}{|l}{} \\
\hline
\end{tabular}




\title{
Viewing CLIL through the eyes of former pupils: Insights into foreign language and intercultural attitudes
}

\author{
Anssi Roiha \\ Department of Language and Communication Studies, University of Jyväskylä, Finland
}

\author{
Mélodine Sommier
}

Department of Media \& Communication, Erasmus University Rotterdam, The Netherlands

\begin{abstract}
This article examines the long-term effects of CLIL on former pupils' foreign language and intercultural attitudes. The 24 participants, who received English-medium CLIL for nine years in the 1990s, were interviewed and the data analyzed using thematic analysis. The participants generally felt that CLIL had had a very positive effect on their target language attitudes. However, many considered that CLIL had affected negatively on their attitudes towards other foreign languages. The perceptions regarding the effect of CLIL on intercultural attitudes diverged more. The study elucidates the longstanding impact CLIL can have on individuals' attitudes yielding insights into future CLIL education.
\end{abstract}

Artikkelissa tarkastellaan CLIL-opetuksen kauaskantoisia vaikutuksia oppilaiden asenteisiin vieraita kieliä sekä kulttuurienvälistä tietoisuutta kohtaan. Tutkimusta varten haastateltiin 24 entistä CLILoppilasta, jotka saivat englanninkielistä CLIL-opetusta 1990-luvulla. Haastatteluaineisto analysoitiin laadullisen sisällönanalyysin keinoin teemoittelemalla. Osallistujien mukaan CLIL-opetuksella oli erittäin positiivinen vaikutus heidän asenteisiinsa englannin kieltä kohtaan. Moni kuitenkin koki, että englannin vahva rooli oli vaikuttanut negatiivisesti heidän suhtautumiseensa muihin vieraisiin kieliin. Näkemykset CLIL-opetuksen vaikutuksista kulttuurienväliseen tietoisuuteen puolestaan vaihtelivat enemmän. Tutkimuksen tulokset havainnollistavat millaisia kauaskantoisia vaikutuksia CLILopetuksella voi olla yksilöiden asenteisiin.

Keywords: CLIL, foreign language attitudes, intercultural attitudes, education, Finland

\section{Introduction}

Content and Language Integrated Learning (hereafter CLIL) is nowadays regarded as one solution to the growing demand of multilingualism in Europe (e.g. Ruiz de Zarobe, 2008). In this article, CLIL is defined as an educational approach that comprises various models of implementation (e.g. Eurydice, 2006; Marsh, Maljers, \& Hartiala, 2001) with the commonality that subject matter is taught through an additional or a foreign language with a dual-focus in mind (i.e. to learn both content and language of instruction) (e.g. Coyle, Hood, \& Marsh, 2010). The majority of CLIL research documents clear advantages regarding 
foreign language learning (Dalton-Puffer, 2011; Pérez-Cañado, 2012). Although the research results on content learning have not been unanimous (e.g. Fernández-Sanjurjo, FernándezCostales, \& Arias Blanco, 2017), many studies suggest that CLIL is not detrimental to it (e.g. Seikkula-Leino, 2007; Surmont, Struys, Van Den Noort, \& Van De Craen, 2016). In addition, CLIL has been claimed to raise intercultural awareness and better prepare pupils for internationalization (e.g. Coyle, Holmes, \& King, 2009; Méndez García, 2012) as well as foster a positive attitude towards multilingualism (e.g. Marsh, 2000).

Lately critical voices have however become more vocal. Previous CLIL studies on learning outcomes have been questioned regarding the lack of pretests with CLIL and control pupils as well as the neglect of the socioeconomic background and pupil selection (e.g. Bruton, 2013). A few recent studies, which have taken the a priori differences between CLIL and non-CLIL pupils into account, have indeed supported the claims that CLIL benefits may have been overemphasized (e.g. Dallinger, Jonkmann, Hollm, \& Fiege, 2016; Rumlich, 2016). In general, the long-term effects of CLIL have not been thoroughly investigated since the approach is still a relatively new phenomenon in many countries (e.g. in Finland, the context of this study, CLIL started in 1991). Existing CLIL research has mostly looked at the pupils' experiences currently enrolled in CLIL programmes. Furthermore, most studies on language attitudes in CLIL have been quantitative (e.g. Lasagabaster \& Sierra, 2009; Merisuo-Storm, 2007; Pihko, 2007; Seikkula-Leino, 2007), highlighting the need for more qualitative approaches on the topic.

The participants of this study are former Finnish CLIL pupils, who received Englishmedium CLIL education during their comprehensive school (i.e. 9 years) in the 1990s. This study focuses on their retrospective views on the influence of CLIL on their foreign language and intercultural attitudes which previous CLIL research has mostly examined separately. In this article, intercultural attitudes is used as an umbrella term that encompasses various 
concepts related to interculturality such as intercultural communication competence, intercultural understanding, or critical cultural awareness to discuss participants' views on intercultural communication. The present study offers a rather unique opportunity to investigate the long-lasting outcomes of CLIL education through former pupils' eyes. However, it is worth acknowledging that CLIL has evolved since the 1990s both in the way it is conceptualized and implemented. Researchers have kept this in mind to avoid anachronism in the analysis.

The specific research question is:

What are the participants' views on the effect of CLIL education on their foreign language and intercultural attitudes?

\section{Foreign language attitudes and CLIL}

Attitudes can be defined and consequently studied in various ways. For instance, an umbrella definition by Eagly and Chaiken (1993, p. 1) suggests that an attitude is 'a psychological tendency, expressed by evaluating a particular entity with some degree of favor or disfavor'. Traditionally, attitudes are seen as consisting of cognitive, affective and behavioral components (Garrett, Coupland, \& Williams, 2003). Researchers disagree whether attitudes should be treated as relatively stable entities as opposed to constructed and situated (e.g. Bohner \& Dickel, 2011). For instance, according to Kalaja and Hyrkstedt (2000) attitudes can be contradictory as they may vary from one situation to another or even within a situation. This research adopts an intermediate stance to the discussion by presuming that all attitudes are constructed and somewhat context-sensitive, however certain attitudes can be more dynamic whereas others may be more enduring (e.g. Eagly \& Chaiken, 2007). Further, we believe attitudes are cognitive and affective in nature and can be, but are not necessarily, manifested in one's behavior. 
According to some of its advocates, one benefit of CLIL is that it results in a more positive attitude towards language learning and multilingualism in general (e.g. Coyle et al., 2010; Marsh, 2000). This issue has not been widely studied but the scarce research conducted seems to support the argument. For instance, Lasagabaster and Sierra (2009) found, in their questionnaire study comprising 287 secondary students in Spanish CLIL context, that CLIL education resulted in a more positive attitude towards the language of instruction in CLIL (i.e. English) as well as the majority (i.e. Spanish) and minority languages (i.e. Basque) than mainstream education. Along with the overall outcome, Lasagabaster and Sierra's (2009) research interestingly revealed that the gap in positive attitudes towards English between CLIL and non-CLIL pupils seemed to be levelling as the pupils got older albeit remaining very prominent.

In Finland, few studies have investigated language attitudes in CLIL. For instance, Merisuo-Storm (2007) found that primary aged CLIL pupils $(\mathrm{n}=70)$ had a significantly more positive attitude towards learning a foreign language than their peers $(n=75)$ in monolingual classes. In Seikkula-Leino's $(2007)$ research, $5^{\text {th }}$ and $6^{\text {th }}$ grade CLIL pupils $(n=116)$ were somewhat more motivated to learn foreign languages than their non-CLIL peers $(n=101)$. Interestingly, however, the CLIL pupils' foreign language learning self-concept (i.e. 'an individual's self-descriptions of competence and evaluative feelings about themselves as a Foreign Language (FL) learner' (Mercer, 2011, p. 14)) was weaker than that of their nonCLIL peers'. Seikkula-Leino (2007) argues this could be related to the challenges posed by learning in general as pupils are exposed to great deal of language that is above their comprehension, which may be difficult for them to cope with. In Pihko's (2007) research, lower secondary CLIL pupils $(\mathrm{n}=209)$ were more motivated to learn the CLIL target language (i.e. English) and had a more positive attitude towards it than their non-CLIL peers $(\mathrm{n}=181)$. 


\section{Intercultural attitudes and CLIL}

Scholars have mostly dealt with theoretical conceptualizations of the relation between CLIL and intercultural communication, and proposed CLIL as a facilitator to raise intercultural awareness (e.g. Coyle, 2007; Marsh et al., 2001; Sudhoff, 2010). Among the most known theories of CLIL pedagogy is the one of Coyle's 4C framework in which she proposes that the cornerstones of successful CLIL education are content, cognition, communication and culture (Coyle, 2007). In addition, culture is one of the five dimensions listed by Marsh et al. (2001) for successful CLIL education. According to the authors, CLIL programmes within European context help to build pupils' intercultural understanding and introduce them to a wider cultural context. Sudhoff (2010) argues that CLIL provides opportunities to encourage students to critically reflect on the different connotations and referential meanings embedded in language use. As a triple-focused approach (i.e. language, content and intercultural learning), CLIL can help examine differences as well as overlaps and similarities between cultural perspectives (Sudhoff, 2010). This echoes recent approaches within intercultural communication which have drawn attention to the co-construction of culture and communication (e.g. Piller, 2011). These views focus on a two-sided process whereby culture is both constructed through and constructive of language and discourse. As a result, intercultural communication competence literature increasingly prioritizes reflexivity or critical cultural awareness as a means of encouraging students to critically reflect on their practices and positionality, and on discourses surrounding them (Byram, Gribkova, \& Starkey, 2002; Dervin, Paatela-Nieminen, Kuoppala, \& Riitaoja, 2012; Martin \& Nakayama, 2015).

In one of the few empirical studies on CLIL and intercultural development, conducted through qualitative interviews in Spain, Méndez García (2012) found that both teachers and 
pupils (primary and secondary) perceived CLIL as influencing positively their attitudes towards otherness and languages as well as fostering critical cultural awareness. Interestingly, and similarly to Lasagabaster and Sierra's (2009) research, the pupils' positive attitudes towards the target language and culture seemed to decrease towards the end of secondary education, which, according to Méndez García (2012), may be due to the changing nature of CLIL compared to primary school. That is, the focus was more on language-related issues, leaving the cultural aspects partly aside. Further, at that stage, CLIL pupils merged with nonCLIL pupils for the first time as they had previously been studying amongst each other.

In addition, some researchers have emphasized the potential of materials used in CLIL to enhance intercultural awareness. Including materials emanating from and representing a wide range of cultural realities has been underlined as a critical aspect to enhance intercultural attitudes by teaching pupils different perspectives and therefore encouraging them to go past ethnocentric reflexes. (Méndez García, 2013; Sudhoff, 2010.) For instance, González Rodrígues and Borham Puyal's (2012) case study examined the potential of using varied authentic literary texts on gender roles in CLIL to encourage higher education students' reflections on their own practices, attitudes and on gender roles in their own and other countries. A majority of the students reported that the activities indeed enhanced their level of self-reflexivity. However, using materials to develop intercultural awareness in CLIL settings contain few challenges. First, the focus on one language might be tied to a focus on one cultural area. Second, the way materials are used, and therefore the role played by teachers, is pivotal. (Méndez García, 2013.)

\section{The context of the study}

CLIL was introduced to the Finnish education system in 1991 due to an amended legislation which enabled schools to provide teaching in other that the official languages (i.e. Finnish and 
Swedish). An official requirement for CLIL in Finland has always been that the general learning objectives of the national curriculum are met regardless of the language of instruction (Finnish National Core Curriculum for Basic Education, 2004). The popularity of the approach has decreased considerably since the early years. That is, in the 1990s, approximately $10 \%$ of comprehensive schools were implementing CLIL whereas in 2005 the number of schools had dropped to 5\%. (e.g. Lehti, Järvinen, \& Suomela-Salmi, 2006; Nikula \& Marsh, 1996). However, an inquiry from 2012 reveals that the interest towards CLIL has again been increasing in many municipalities (Kangasvieri, Miettinen, Palviainen, Saarinen, \& Ala-Vähälä, 2012). The dominant CLIL language in Finland has indisputably been English (e.g. Lehti et al., 2006). Across countries, CLIL has been implemented in multiple ways, thus different CLIL models have their idiosyncrasies which poses its challenges to the transferability of research results. Furthermore, the present study examines CLIL in the 1990s and both the conceptualization and implementation of CLIL has changed since then. Hence, the CLIL context of the study is extensively described hereafter.

\section{CLIL in the target school}

The CLIL programme in the target school was launched in 1991 and the participants of the study commenced their school in 1992. The rationale behind the implementation of CLIL was mostly the increasing need for a basic command of English in an international and global world. Furthermore, the promising experiences from the immersion education in Canada coupled with active parents in the community also supported the start of a CLIL programme. The primary aims of the programme were to make pupils confident and competent language users and provide them with appropriate skills to function in an increasingly international society, thus being in line with the objectives of other European CLIL models (e.g. Maljers, 
Marsh, \& Wolff, 2007). Pupils willing to enroll in the CLIL class were not subjected to a pretest. The CLIL classes of the school were however partially selective, that is, pupils who had some prior experience of English had priority over others. Additionally, a requirement was that pupils did not have challenges in their basic cognitive skills, which was assessed based on the preschool teachers' observations. The number of applicants outnumbered the places in the target year, thus most of the pupils had to be selected randomly.

In the $1^{\text {st }}$ and $2^{\text {nd }}$ grades (age 7-8), CLIL was realized on a daily basis mostly through class routines, songs, rhymes and games. Starting from the $3^{\text {rd }}$ grade, the amount of CLIL teaching increased. On average, approximately $25 \%$ of the instruction was given in English. CLIL was implemented in all subjects except Finnish. The content of the CLIL lessons derived from the national curriculum. Additionally, the formal English teaching, which usually started in the $3^{\text {rd }}$ grade, followed a more intensive instruction. The CLIL programme continued in lower secondary school (grades 7-9, age 13-15) albeit the amount of CLIL decreased drastically and it was carried out sporadically. It was nevertheless implemented in most subjects but less consistently and further diminished towards the end of the school. For instance, the optional courses and different subjects opted by the pupils posed its challenges to employ CLIL as extensively as at primary level.

\section{Methodology}

\section{Data}

The data for this study comprises 24 individual in-depth interviews. The interviews were semi-structured and followed broad themes that were sent to the participants in advance. The themes (see Appendix 1) derived from literature and previous research as well as a pilot study conducted by one of the researchers (Roiha, 2017). Additionally, some topics were raised in the first few interviews which were addressed also in the subsequent ones. This type of 
method was chosen to get insights into the participants' viewpoints about their own experiences and life trajectories and give them opportunities to construct their own meanings along the lines of interest for the research project (e.g. Hirsjärvi \& Hurme, 2011). Detailed information about the interviews is presented in Appendix 2.

The researcher who conducted the interviews (Author 1) had a personal experience as a pupil in the target class and thus a prior relation to the participants which may have potentially affected some of their narrations. However, at the start of each interview, the researcher encouraged the participants to honestly express their views, both positive and negative ones. Furthermore, to minimize the social desirability bias and to scrutinize the participants' genuine perceptions, the researcher approached the different themes at different stages of the interviews by making use of both direct and indirect procedures. In other words, some interview questions dealt overtly with foreign language and intercultural attitudes whereas others tackled them more indirectly.

\section{Data analysis}

The data were analyzed using a theoretically oriented thematic analysis. The analysis was informed by Braun and Clarke's (2006) guidelines. That is, the data were read through and coded through systematic and successive stages. First, the transcribed interviews were carefully read through several times. Second, the whole data were preliminary coded. Following this stage, the extracts that were considered relevant to the research question were selected for this study (approx. 1/5 of the overall data) and analyzed further in-depth. At this stage, a lot of overlapping still existed as some extracts fitted into several coding categories. Third, the coded categories were further analyzed and the recurrent main themes and their sub-themes started to be identified (see Appendix 3). The data excerpts corresponding to those themes were organized accordingly in a separate word file. Fourth, the formed themes 
were further reviewed and refined which resulted in combining several themes and forming the final themes. Furthermore, some themes were still eliminated from the analysis as they were considered not corresponding to the research question. Last, the final themes were named (see Appendix 4). Steps 1-3 of the analysis were done by Author 1, from step 4 onwards both authors analyzed the data.

\section{Participants}

The participants of this study are 24 former pupils who were enrolled in the target CLIL class. During the nine-year comprehensive school, overall 28 pupils (excluding the researcher) studied in the class at some stage. Most participants studied in the class the whole 9-yearperiod, however some joined the class only later on and few moved to another municipality during the comprehensive school. Two participants decided to transfer to a non-CLIL lower secondary school due to its better reputation. An invitation to participate in the research was sent out to all of them via Facebook. Finally, 24 (i.e. 85\%) agreed to be interviewed. All the participants signed a letter of consent at the outset of the research process and were given pseudonyms to ensure their anonymity.

Only five participants had some experience of English prior to the CLIL programme as they had either been living in an English-speaking country or attending an Englishspeaking school abroad. Many participants (11/24) however had received minor Englishmedium instruction already in preschool. Table 1 outlines the participants of the study and the grades in which they studied in the CLIL class.

[Table 1 near here]

\section{Results}


Following a thorough thematic analysis, the researchers identified three main categories from the data in relation to foreign language and intercultural attitudes: (1) dominance of English, (2) other foreign languages and (3) (cultural) differences.

\section{Dominance of English}

In general, the participants described CLIL as a very positive and beneficial experience to them. Similar impressions have been recorded in previous CLIL research both at primary and secondary levels (e.g. Pihko, 2010; Pladevall-Ballester, 2015). In the participants' view, CLIL had formed a highly positive attitude towards the target language (i.e. English). Most of them reported enjoying using English and described it as 'fun', 'natural', 'useful', 'easy' or 'pleasant'.

Age has been a relevant factor in foreign language attitudes as previous research has documented a decline in positive attitudes as pupils advance in school (e.g. Cenoz, 2004). The participants in this study did not follow this trend, as for the majority of them, their attitudes towards English seemed to remain positive or even somewhat increase as they proceeded to upper secondary school and merged with non-CLIL pupils in English lessons. Many emphasized how, at that point, they started to realize their advantage over others as regards English competence:

(1) There [upper secondary school] I felt like it was probably like the biggest benefit so far.. this content-based English [teaching].. there you felt like the difference was the greatest compared to others.. and that it was somehow very easy and I was never like anxious to speak English. (Kalle) ${ }^{2}$ 
Most participants even brought forth issues of superiority as language users which highlights their positive stance towards English and the role CLIL had in the process. As Kalle's quote implies, comparing themselves to others seemed to further boost their self-confidence as language users and consequently form an even more positive attitude towards English. Furthermore, based on their narrations and life course, it seems plausible that the participants' positive attitudes towards English had been constantly constructed in their social interactions keeping them rather stable and enduring. This finding contradicts some of the previous CLIL studies (e.g. Méndez Garcìa 2012; Lasagabaster \& Sierra, 2009). Few participants in the present study also reported a downturn in their positive attitudes towards English as they got older. However, they were mostly the ones who had transferred to a mainstream education, thus limiting their CLIL experience only to primary level.

English was the dominant foreign language for most participants and still actively present in their lives. The most common context for their English language use was their workplace. In general, the participants felt very positively towards the use of English at work and many considered English language proficiency giving them prestige among co-workers. For instance, Jonne, who worked as a practical nurse, mentioned how his colleagues consulted him when dealing with English documents and according to Kalle, his superior often asked him to proofread important emails written in English. Similarly, Juho exemplified the advantages of an excellent command of English at work:

(2) Even though the content wouldn't be that amazing but if you know.. if you know how to express yourself well in English you seem smarter than you are.. so I bet that partly because of that I got there [to my work].. that there [at work] I got some sort of appreciation because I knew English well. (Juho) 
Only two participants stated that in the current situation they would choose another CLIL language than English (i.e. Chinese and Arabic) because they felt that the command of those languages would be a better asset in global working life. All the other participants declared that they would still prefer to go through CLIL education in English which highlights the predominant role English had in their lives in comparison with other foreign languages. Kaapo elaborated on the issue as follows:

(3) Well English is such an international language.. that it.. it's like.. you can pretty much get along with it everywhere.. or at least in many places and it.. anyway gives quite a lot more options than for instance if you would go through things in Swedish or Russian the options are after all a bit narrower that what you get then. (Kaapo)

Kaapo analyzed the benefits of English-medium CLIL through the international prospects it offered. He felt that CLIL had provided him with sufficient language skills that enabled him to live and work abroad as he had lived in several countries. Tuukka, in turn, had adopted an even more extreme stance on the importance of mastering English:

(4) In a way you don't need other languages then if you know English.. I don't in a way understand the logic of some people who want to learn several languages because you can manage with English almost everywhere. (Tuukka)

Although the quotes partly mirror the participants' positive attitude towards English and imply the significance of CLIL in that regard, they may also reflect a more general language ideology as English has indisputably been the most common and known foreign language in Finland since the 1990s and is actively present in various domains of life (e.g. Leppänen et al., 2011). What Tuukka's quote more clearly articulates, is that he does not endorse the 
promoted relation of CLIL and positive attitudes to multilingualism. Overall in the interviews, other languages were generally depicted somewhat negatively, a matter which will be discussed in more detail as follows.

\section{Attitudes towards other foreign languages}

In contrast to the overtly positive attitude towards English language, the participants had somewhat differing views on the effects of CLIL on learning other languages. Few participants considered CLIL benefited language learning in general. For instance, Pasi claimed being proficient in six languages and speculated that CLIL may have boosted his selfconfidence as a language learner. Marko, in turn, discussed whether he would have studied German as an additional language already in primary school had he not received CLIL education:

(5) If English wouldn't have felt so strong at that point, then it would have probably been.. sort of starting another language would have felt.. there could have been a bigger threshold for it. (Marko)

Most participants however drew a clear distinction between learning English and other foreign languages. For instance, languages such as German or Swedish, which were respectively the next foreign languages to most participants, were generally depicted as useless and arduous. The participants' views contradict the alleged benefits of CLIL on positive attitudes towards languages in general (e.g. Coyle et al., 2010; Marsh, 2000) which few empirical studies have supported (e.g. Lasagabaster \& Sierra, 2009; Merisuo-Storm, 2007). On the contrary, the strong focus on the target language was perceived as detrimental to language learning by many participants. For instance, Juho referred to the phenomenon by noting that due to the implicit learning of English through CLIL, he had not acquired the 
'tools to learn a [foreign] language'. Additionally, Niko and Jonne elaborated on the issue as follows:

(6) Sometimes I've wondered that.. for me the next languages after that were.. for instance German was pretty hard to start so is it.. is it that you haven't like.. English has been too easy and then the next language hasn't.. I don't know.. I don't know if there is any truth in this but you haven't like had to study a language except only later on.. so I have sometimes thought that it has maybe slowed it down. (Niko)

(7) When you compared it to that that English was so strong and it was so natural so then you didn't know how to start studying another language in a way by cramming and fighting for real. (Jonne)

The quotes illustrate how, in the participants' view, CLIL seemed to partly hinder the formal learning of other foreign languages, although previous studies have contrarily indicated that bilingualism would rather benefit the learning of additional languages (e.g. Cenoz, 2013). As a result, this seemed to have affected negatively on their attitudes to other foreign languages. Additionally, Niko and Jonne's quotes reveal how they had learned English through language use and focusing on meaning. In turn, they recalled that other foreign languages were taught following more form-focused instruction. Therefore, adopting CLIL methods and practices to foreign language education in general could lead to more positive foreign language attitudes. However, it is noteworthy that the participants in this study received their basic education already in the 1990s and language education has evolved, to some extent, since then. Furthermore, the relation between CLIL and foreign language attitudes was not that straightforward as few participants expressed additional reasons alongside CLIL in forming their attitudes towards other languages, such as peers' opinions or the societal status of a 
language. Consequently, in CLIL setting, it seems pivotal to explicitly address other foreign languages in a positive light. For instance, it may be feasible to make use of pupils' different language backgrounds which offers a natural way of making languages relevant and thus normalizing multilingualism.

Interestingly, few participants articulated positive opinions about multilingualism due to CLIL but seemed to define it mostly as the command of English and Finnish, thus adopting the broad definition of multilingualism, as the use of at least two languages (e.g. Aronin \& Singleton, 2008). For instance, Jukka first expressed positive views towards multilingualism and acknowledged the role of CLIL in forming his attitudes. However, later during the interview he specified that the only important languages for Finns, in his opinion, are English and Finnish. He further elaborated his view by explaining that he had never been in a situation where he was not able to cope with English. This further highlights the dominant status of English in the participants' lives.

\section{Intercultural attitudes}

The participants' views of the effect of CLIL on their intercultural attitudes were not equally unanimous. Many participants however felt that CLIL directly affected their attitudes and enhanced their overall interest towards international and intercultural aspects. Few saw the teaching resulting in more positive attitudes towards differences because of the values embedded in CLIL itself:

(8) It [CLIL education] has absolutely also these kinds of soft values.. tolerance.. that it has anyway sort of made it possible that.. that you understand different [people].. other than Finns. (Kimmo) 
Echoing Kimmo's words, few of the participants referred to celebrations and traditions in different cultural contexts which were discussed in CLIL lessons, and explained that dealing with culture prompted their interest towards other practices and groups:

(9) It might be that it could affect so that I wouldn't be that interested in these kinds of different cultures.. that that.. it would probably be a big part.. big part away from my life. (Annika)

In addition to the content of CLIL education, many pupils felt that the heterogeneity of the classroom also shaped their attitudes towards difference:

(10) I think that because we were.. in comprehensive school there were those among us who had lived in different countries and then we also maybe someway explored those cultures.. so somehow it is.. I think that somehow you are kind of more open.. or somehow towards new things. (Jere)

Jere recalls a certain degree of diversity within the class, which can partly be explained by the class being somewhat heterogeneous compared to Finnish schools at that time and to other classes in the school. Even though classroom diversity is not a direct condition of CLIL, in the context of this study diversity and CLIL were intertwined as some of the pupils with international experiences chose the CLIL class due to its English-medium teaching. The level of diversity was, however, limited to different nationalities, pupils who had a bilingual background and nationals who had lived abroad. That is, even though pupils had varied sets of international experiences, they formed a somewhat homogenous group, for instance regarding social class. In that regard, the emphasis on international diversity in language 
education has been criticized for giving a distorted view of what diversity can encompass and creating a false sense of heterogeneity (Cole \& Meadows, 2013).

Many participants felt that CLIL had influenced their values and attitudes in an indirect way. They for instance expressed that CLIL, and the positive English language selfconcept it shaped, encouraged them to actively engage in interactions with foreign speakers. Many consequently linked CLIL education to eventually creating a more positive attitude towards foreigners and foreign cultures:

(11) I was on an exchange during my [university] studies and then also in contact a lot with exchange student coming to Finland.. so the language competence made it possible that you got along well with them.. and then it has perhaps opened this kind of interest towards other cultures.. once you have lived abroad the threshold to move for work is probably a hundred times lower.. so this all relates to each other and I feel that the language competence has made it possible that you haven't had to feel ashamed of your own language competence or to restrict yourself in conversations with foreigners. (Niko)

The quote illustrates that for many participants, CLIL education seemed to benefit their intercultural attitudes mostly due to the language skills and self-concept they acquired which worked as a facilitator in interacting with foreign speakers. The participants mentioned both their confidence as language users, which seemed to stimulate their interest and positive outlook towards difference, as well as the subsequent impression that interactions went well thanks to their language skills. Marko used the idiom 'building bridges' (sillanrakentaja) to encapsulate the role of English as shaped by CLIL. This echoes previous research which also found that CLIL pupils are more willing to communicate and interact with foreign speakers than their non-CLIL peers (e.g. Pihko, 2007). Regarding the participants of this study, their willingness to communicate with foreigners appeared to have lasted until adulthood. 
When discussing the intercultural dimension of CLIL, many participants explicitly stated that they consider themselves to be very tolerant and open to other cultures. In addition, a prominent number of the participants had an internationally oriented work. This is in line with the aim of their CLIL programme which intended to provide pupils with tools to take their place in an international society. Many of the pupils indeed reflected on the effects that CLIL may have had on their lives, including social networks, career paths and values:

(12) With English it has just made so many other things possible.. studying and then friends from other countries and.. and a work career so everything has been like easier because of the language skills.. it could be that I wouldn't live abroad [without CLIL].. somehow I would probably have a tighter connection to Finns and somehow maybe a bit more sort of Finland centred worldview.. now somehow my mindset is the contrary that Finnish issues don't interest me anymore that much. (Niko)

Niko's quote illustrates the assumption that being interculturally competent entails prioritizing internationality over locality. However, this hierarchy has been criticized for building on and strengthening 'exaggerated portrayals of inter-national diversity and intra-national homogeneity' (Cole \& Meadows, 2013, p. 30). In contrast, intercultural communication competence has been increasingly theorized around the notion of reflexivity that would help students distance themselves from a priori discursive constructions of cultural realities and encourage pupils to critically reflect on their experiences and positionality (Martin \& Nakayama, 2015).

Few participants, on the other hand, explicitly stated that they did not consider CLIL affecting their attitudes towards foreign issues and difference. They rather emphasized the significance of family background or outside school experiences such as travelling or living abroad in shaping their intercultural attitudes. None of the participants however considered 
CLIL as detrimental to their views to difference although few were somewhat discrepant in their narrations. For instance, on the one hand, Juho asserted that CLIL had had a positive effect on his attitudes towards foreigners and differences. On the other hand, he sometimes expressed very stereotypical and prejudicial views about different nationalities. In the following quote, Juho talks about his peers in an international degree programme:

(13) The worst were Chinese and in some case Russians.. Chinese were like.. it was very hard to get along with them even though it was always emphasized to us in all things that there are cultural differences and so.. but they are in their own world sort of.. that somehow it felt that sometimes they.. their worldview is truly.. totally different.. that they don't like.. like un.. they don't think the same way as we do.. there are like those exceptions.. often they are then the ones who have lived in some western countries.. or that.. but who are like.. hard to say that who are very smart.. cause the others aren't probably stupid either but.. that there are.. there are those individuals with whom it is.. easy for a Westerner to get along with.. that there are those as well. (Juho)

Juho's quote is underpinned by ethnocentric views and a differential approach to intercultural communication (Dervin, 2011). That is, the emphasis is put on differences between people and revolves around static images of nationals who are judged based on how much they differ from the Western norms and expectations. In general, it seemed that most participants referred to intercultural communication through the lens of differences and by focusing on specific groups of speakers, nationalities and/or cultures. (e.g. focus on British and U.S. cultures, perception of the world divided between Finland and others). In that regard, the participants' narratives sometimes echoed traditional models of intercultural communication competence articulated around solid views of cultural 'others'. These models, and resulting trainings, typically aim to increase one's ability to communicate with interlocutors whose (perceived) 
difference is based on static characteristics. The essentialist underpinnings of such models correspond to the overarching idea that intercultural communication competence can be acquired rather than being constantly and contextually developed (Martin \& Nakayama, 2015).

Few participants expressed more complex and nuanced views of differences in relation to their experiences of living or working abroad. However, their views sometimes also oscillated between positive views of interculturality, as communication and culture being performed in interactions, and stereotypical judgments of others. These contradictions echoed 'Janusian' views of intercultural communication that emphasize the co-construction of culture on the one hand, while maintaining a differential approach on the other. A 'Janusian' perspective therefore 'juggles with discourses that are liquid (open-endedness, (inter)individualism) and solid (culturalism, differentialism) at the same time.' (Dervin, 2011, p. 47). Discrepancies in the participants' narrations therefore draw attention to the limits of the positive attitudes they claim to have towards international and intercultural issues. This raises questions as to whether few participants were being politically correct and moderating some of their views. Furthermore, this suggests ambivalent intercultural attitudes that might be limited to public discourse and/or to certain situations and types of difference. It also illustrates how attitudes are not necessarily static and fixed but in contrast may vary depending on situation and can even be contradictory (Kalaja \& Hyrkstedt, 2000).

Based on this study, CLIL appears to have potential in developing enduring positive intercultural attitudes. However, the findings suggest that CLIL does not automatically provide students with adequate tools to develop intercultural communication competence in a long-lasting manner. Limitations to the participants' intercultural competence could suggest that CLIL can play a role in developing pupils' intercultural attitudes though not necessarily providing students with tools to develop intercultural communication competence across time 
and contexts. Encouraging pupils to critically reflect on different elements, as suggested by previous studies on CLIL and intercultural communication (e.g. Méndez García, 2013; Sudhoff, 2010), could help develop their intercultural attitudes in the long-term.

\section{Conclusion}

This study focused on the effects of CLIL on foreign language and intercultural attitudes from the participants' perspectives. The findings strongly suggest that CLIL education had formed a very positive attitude towards the target language which seemed to be rather enduring and persistent. Through CLIL, English had become a salient language for most participants and remained actively present in their lives. This finding is in accordance with previous studies on the issue (e.g. Lasagabaster \& Sierra, 2009; Pihko, 2007), thus further supporting the assumption that CLIL approach, in which a foreign language is used in communication and learning content, appears to be very effective in relation to the target language attitudes. The fact that CLIL started already at primary level appeared to have a significant role in forming the participants' attitudes towards English which justifies the implementation of early CLIL education.

Many participants felt that CLIL had impeded the learning of and effected negatively on their attitudes towards other foreign languages, which is contradictory to previous studies (e.g. Lasagabaster \& Sierra, 2009; Merisuo-Storm, 2007). However, few participants also mentioned sociocultural reasons, such as peers or societal status, in forming their attitudes towards other languages. This finding nevertheless yields insight into language teaching in general. In the present context, other foreign languages were taught following more formfocused instruction which was also expressed by few of the participants in the interviews. Therefore, adopting CLIL methods and practices to foreign language education in general could lead to more positive foreign language attitudes. However, it is important to keep in 
mind that the participants were reflecting on their school experiences from the 1990s and that language education has evolved, to some extent, since then.

Lastly, CLIL had offered a potential context to develop positive intercultural attitudes which is in line with Méndez García’s (2012) case study. Based on this study, there however seems to be a need for explicit attention to interculturality also in CLIL for it to have a longlasting and in-depth effect. The participants did not receive formal intercultural communication training during their CLIL education. The description of the programme however hinted at intercultural communication by referring to the increasingly international word, even though, in practice, the intercultural aspect was mostly tackled indirectly and related to the teaching of language and culture. This may partly explain why not all the participants saw a direct relation between CLIL and their intercultural attitudes. Nevertheless, many of them expressed positive attitudes towards international, intercultural and linguistic differences even though discrepancies in some of their testimonies suggested ambivalent intercultural attitudes. The participants of this study attended school in the 1990s and since then increasing attention has been paid to include intercultural issues in CLIL education (e.g. Coyle, 2007; Sudhoff, 2010). It is however important to consider how intercultural issues have been included and to examine which trainings are offered to CLIL teachers since their role and competence to deal with and teach about difference/otherness is critical (see e.g. Sommier \& Roiha, 2018).

The present study has some limitations which are important to bear in mind. First, the target CLIL programme may differ from other CLIL models in some respect as CLIL in Europe has been implemented in various ways (e.g. Eurydice, 2006). Therefore, the results of this study may be somewhat context specific. Furthermore, the time period of the CLIL programme may also be of significance when interpreting the results. Second, many participants felt that other features alongside CLIL had affected their attitudes. However, a 
detailed scrutiny of the impact of other factors on the participants' attitudes were left outside the scope of this article and could therefore be further researched. Third, it would be interesting to conduct a similar research with pupils who received CLIL education in a language that would not have the prevalent status of English to limit the outside CLIL effects on the participants' language attitudes. Last, the participants were reflecting on their CLIL experiences retrospectively, which may have its influence on the narrations (e.g. McAdams, 2008). Despite these limitations, this study contributes to the growing body of CLIL research and yields interesting insights into the long-term effects of the approach.

\section{Notes}

${ }^{1}$ The background information of the target programme is based on an informal interview with the school's former teacher as well as old programme brochures. In addition, one of the authors (Author 1) has a personal experience as a pupil in the target CLIL class.

2 The interviews were conducted in Finnish and transcribed verbatim by Author 1. The extracts used in this article were translated into English by Author 1. The quotes are presented in their original language (Finnish) in Appendix 5. The notation (..) indicates a pause in the speech. Words in square brackets are added by the researcher to clarify the context of the utterance.

${ }^{3}$ The letter in the brackets indicates the participant's sex. $(M)=$ male, $(F)=$ female

\section{Disclosure statement}

No potential conflict of interest was reported by the authors.

\section{References}


Aronin, L., \& Singleton, D. (2008). Multilingualism as a new linguistic dispensation. International Journal of Multilingualism, 5, 1-16.

Bohner, G., \& Dickel, N. (2011). Attitudes and Attitude Change. Annual Review of Psychology, 62, 391-417.

Braun, V., \& Clarke, V. (2006). Using thematic analysis in psychology. Qualitative Research in Psychology, 3, 77-101.

Bruton, A. (2013). CLIL: Some of the reasons why... and why not. System, 41, 587-597.

Byram, M., Gribkova, B., \& Starkey, H. (2002). Developing the intercultural dimension in language teaching. A practical introduction for teachers. Strasbourg: Council of Europe.

Cenoz, J. (2004). Teaching English as a Third Language: The Effect of Attitudes and Motivation. In C. Hoffmann \& J. Ytsma (Eds.), Trilingualism in Family, School, and Community (pp. 202-218). Clevedon: Multilingual Matters.

Cenoz, J. (2013). The influence of bilingualism on third language acquisition: Focus on multilingualism. Language Teaching, 46, 71-86.

Cole, D., \& Meadows, B. (2013). Avoiding the essentialist trap in intercultural education. Using critical discourse analysis to read nationalist ideologies in the language classroom. In F. Dervin \& A. J. Liddicoat (Eds.), Linguistics for Intercultural Education (pp. 29-48). Amsterdam: John Benjamins Publishing.

Coyle, D. (2007). Content and Language Integrated Learning: Towards a Connected Research Agenda for CLIL Pedagogies. International Journal of Bilingual Education and Bilingualism, 10, 543-562.

Coyle, D., Holmes. B., \& King, L. (2009). Towards an integrated curriculum: CLIL national statement and guidelines. London: The Languages Company. 
Coyle, D., Hood, P., \& Marsh, D. (2010). CLIL: Content and language integrated learning. Cambridge University Press.

Dallinger, S., Jonkmann, K., Hollm, J., \& Fiege, C. (2016). The effect of content and language integrated learning on students' English and history competences - Killing two birds with one stone? Learning and Instruction, 41, 23-31.

Dalton-Puffer, C. (2011). Content-and-language integrated learning: from practice to principles? Annual Review of Applied Linguistics, 31, 182-204.

Dervin, F. (2011). A plea for change in research on intercultural discourses: A 'liquid' approach to the study of the acculturation of Chinese students. Journal of Multicultural Discourses, 6, 37-52.

Dervin, F., Paatela-Nieminen, M., Kuoppala, K., \& Riitaoja, A. L. (2012). Multicultural Education in Finland: Renewed Intercultural Competences to the Rescue? International Journal of Multicultural Education, 14.

Eagly, A. H., \& Chaiken, S. (1993). The psychology of attitudes. Fort Worth: Harcourt Brace Jovanovich College Publishers.

Eagly, A. H., \& Chaiken, S. (2007). The advantages of an inclusive definition of attitude. Social Cognition, 25, 582-602.

Eurydice. (2006). Content and language integrated learning (CLIL) at school in Europe. $\begin{array}{lll}\text { Brussels: } & \text { Eurydice. } & \text { Retrieved }\end{array}$ http://www.indire.it/lucabas/lkmw_file/eurydice/CLIL_EN.pdf

Fernández-Sanjurjo, J., Fernández-Costales, A., \& Arias Blanco, J. M. (2017). Analysing students' content-learning in science in CLIL vs. non-CLIL programmes: empirical evidence from Spain. International Journal of Bilingual Education and Bilingualism. Advanced online publication. 
Finnish National Core Curriculum for Basic Education. (2004). Helsinki: The Finnish National Board of Education. Retrieved from http://www.oph.fi/english/curricula_and_qualifications/basic_education/curricula_2004

Garrett, P., Coupland, N., \& Williams, A. (2003). Investigating Language Attitudes: Social Meanings of Dialect, Ethnicity and Performance. University of Wales Press.

González Rodríguez, L. M., \& Borham Puyal, M. (2012). Promoting intercultural competence through literature in CLIL contexts. Journal of the Spanish Association of AngloAmerican Studies, 34, 105-124. Retrieved from: https://www.atlantisjournal.org/old/ARCHIVE/34.2/06_absrtract_\%20LuisayMiriam.pd f

Hirsjärvi, S., \& Hurme, H. (2011). Tutkimushaastattelu. Teemahaastattelun teoria ja käytäntö [A research interview. The theory and practice of thematic interviews]. Helsinki: Gaudeamus.

Kalaja, P., \& Hyrkstedt, I. (2000). "Heikot sortuu elontiellä”: Asenteista englannin kieleen [On attitudes towards English]. In P. Kalaja \& L. Nieminen (Eds.), Kielikoulussa - kieli koulussa [In a language school - language in school] (pp. 369-386). Jyväskylä: AFinLA yearbook.

Kangasvieri, T., Miettinen, E., Palviainen, H., Saarinen, T., \& Ala-Vähälä, T. (2012). Selvitys kotimaisten kielten kielikylpyopetuksen ja vieraskielisen opetuksen tilanteesta Suomessa. Kuntatason tarkastelu [A report of the situation of national language immersion and CLIL education in Finland. A municipal level inquiry]. University of Jyväskylä: Centre for Applied Language Studies.

Lasagabaster, D., \& Sierra, J. M. (2009). Language Attitudes in CLIL and Traditional EFL Classes. International CLIL Research Journal, 1, 4-17. Retrieved from http://www.icrj.eu/12/article1.html 
Lehti, L., Järvinen, H.-M., \& Suomela-Salmi, E. (2006). Kartoitus vieraskielisen opetuksen tarjonnasta peruskouluissa ja lukioissa [An inquiry about the status of CLIL education in comprehensive schools and high schools]. In P. Pietilä, P. Lintunen \& H.-M. Järvinen (Eds.), Kielenoppija tänään - Language learners of today (pp. 293-313). Jyväskylä: AFinLA yearbook.

Leppänen, S., Pitkänen-Huhta, A., Nikula, T., Kytölä, S., Törmäkangas, T., Nissinen, K., ... Jousmäki, H. (2011). National Survey on the English Language in Finland: Uses, Meanings and Attitudes. Helsinki: Studies in Variation, Contacts and Change in English. Retrieved from http://www.helsinki.fi/varieng/series/volumes/05/

Maljers, A., Marsh D., \& Wolff, D. (2007). Windows on CLIL : content and language integrated learning in the European spotlight. Alkmaar: European Platform for Dutch Education.

Marsh, D. (2000). Using languages to learn and learning to use languages. Finland: $\begin{array}{llll}\text { University of } & \text { Jyväskylä. } & \text { Retrieved }\end{array}$ http://archive.ecml.at/mtp2/clilmatrix/pdf/1uk.pdf

Marsh, D., Maljers, A., \& Hartiala, A.-K. (2001). Profiling European CLIL classrooms. University of Jyväskylä \& European Platform for Dutch Education.

Martin, J. N., \& Nakayama, T. K. (2015). Reconsidering intercultural (communication) competence in the workplace: A dialectical approach. Language and Intercultural Communication, 15, 13-28.

McAdams, D. P. (2008). Personal narratives and the life story. In O. P. John, R. W. Robins \& L. A. Pervin (Eds.), Handbook of personality:Theory and research (pp. 241-261). New York: Guilford Press. 
Méndez García, M. C. (2012). The potential of CLIL for intercultural development: a case study of Andalusian bilingual schools. Language and Intercultural Communication, 12, 196-213.

Méndez García, M. C. (2013). The intercultural turn brought about by the implementation of CLIL programmes in Spanish monolingual areas: a case study of Andalusian primary and secondary schools, The Language Learning Journal, 41, 268-283.

Mercer, S. (2011). Towards an understanding of language learner self-concept. Dordrecht: Springer.

Merisuo-Storm, T. (2007). Pupils' attitudes towards foreign-language learning and the development of literacy skills in bilingual education. Teaching and Teacher Education, $23,226-235$.

Nikula, T., \& Marsh, D. (1996). Kartoitus vieraskielisen opetuksen tarjonnasta peruskouluissa ja lukioissa [An inquiry about the status of CLIL education in comprehensive and high schools]. Helsinki: The Finnish National Board of Education.

Pérez-Cañado, M. L. (2012). CLIL research in Europe: past, present, and future. International Journal of Bilingual Education and Bilingualism, 15, 315-341.

Pihko, M.-K. (2007). Minä, koulu ja englanti. Vertaileva tutkimus englanninkielisen sisällönopetuksen ja perinteisen englannin opetuksen affektiivisista tuloksista [Me, school and English. A comparative study of the affective outcomes of English teaching in content and language integrated (CLIL) classes and in traditional foreign language classes]. University of Jyväskylä: Department of teacher education, Research report 85.

Pihko, M.-K. (2010). Vieras kieli kouluopiskelun välineenä. Oppilaiden kokemuksista vihjeitä CLIL-opetuksen kehittämiseen [Learning through a foreign language. Learners' personal learning experiences as a source of ideas for developing pedagogical practices in 
Content and Language Integrated Learning (CLIL) classes]. University of Jyväskylä: Department of teacher education, Research report 88.

Piller, I. (2011). Intercultural Communication: A Critical Introduction. Edinburgh University Press.

Pladevall-Ballester, E. (2015). Exploring primary school CLIL perceptions in Catalonia: students', teachers' and parents' opinions and expectations. International Journal of Bilingual Education and Bilingualism, 18, 45-59.

Roiha, A. (2017). CLIL-opetuksen merkitys elämänkulkujen rakentajana: kahden entisen oppilaan pohdintoja. [The significance of CLIL as a constructor of life courses: two former pupils' reflections]. In S. Latomaa, E. Luukka \& N. Lilja (Eds.), Kielitietoisuus eriarvoistuvassa yhteiskunnassa - Language awareness in an increasingly unequal society (pp. 257-277). Jyväskylä: AFinLA yearbook.

Ruiz de Zarobe, Y. (2008). CLIL and foreign language learning: A longitudinal study in the Basque country. International CLIL Research Journal, 1, 60-73. Retrieved from http://www.icrj.eu/11/article5.html

Rumlich, D. (2016). Evaluating bilingual education in Germany: CLIL students' general English proficiency, EFL self-concept and interest. Frankfurt am Main: Peter Lang.

Seikkula-Leino, J. (2007). CLIL Learning: Achievement Levels and Affective Factors. Language and Education, 21, 328-341.

Sommier, M., \& Roiha, A. (2018). Dealing with culture in schools: A small-step approach towards anti-racism in Finland. In A. A. Alemanji (Ed.) Antiracism Education In and Out of Schools (pp. 103-124). London: Palgrave Macmillan.

Sudhoff, J. (2010). CLIL and Intercultural Communicative Competence: Foundations and Approaches towards a Fusion. International CLIL Research Journal, 1, 30-37. Retrieved from http://www.icrj.eu/13/article3.html 
Surmont, J., Struys, E., Van Den Noort, M., \& Van De Craen, P. (2016). The effects of CLIL on mathematical content learning: A longitudinal study. Studies in Second Language Learning and Teaching, 6, 319-337. 


\section{Appendix 1: Themes of the interviews}

\section{Background information}

- Which year did you start CLIL?

- How many years did your CLIL studies last?

- Tell about your CLIL education (e.g. which subjects, how many lessons per week, how was it implemented?)

\section{Experiences of CLIL education}

- How did CLIL education feel?

- What was positive about it?

- What was negative about it?

- What would you improve about it?

3. Study history

- What did you study after comprehensive school?

- What role has the CLIL experience played in those studies?

\section{Work history}

- How has your work career been like?

- What role has the CLIL experience played in your work career?

\section{Family/leisure}

- In what ways has the CLIL experience shown in other domains of your life? (e.g. social relations, media consumption, activities)

\section{Attitudes and values}

- What role has CLIL had as regards your attitudes and values? (e.g. multilingualism, interculturality) 


\section{Appendix 2: The interview details}

\begin{tabular}{|l|l|c|l|}
\hline Pseudonym & Date & Duration & Venue \\
\hline Anna (F) & 8.9 .2016 & $58: 04$ & researcher's home \\
\hline Annika (F) & 19.9 .2016 & $41: 37$ & researcher's home \\
\hline Arttu (M) & 1.10 .2016 & $39: 18$ & hotel lobby \\
\hline Eemeli (M) & 11.9 .2016 & $45: 44$ & researcher's home \\
\hline Emmi (F) & 17.9 .2016 & $40: 22$ & university library \\
\hline Hanna (F) & 15.11 .2016 & $30: 17$ & researcher's home \\
\hline Jere (M) & 24.1 .2017 & $38: 35$ & via Skype \\
\hline Jonne (M) & 30.9 .2016 & $45: 55$ & participant's home \\
\hline Juho (M) & 1.10 .2016 & $69: 03$ & participant's home \\
\hline Jukka (M) & 6.9 .2016 & $34: 54$ & researcher's home \\
\hline Kaapo (M) & 26.1 .2017 & $36: 10$ & via Skype \\
\hline Kalle (M) & 1.10 .2016 & $37: 15$ & participant's home \\
\hline Kimmo (M) & 10.12 .2016 & $63: 18$ & participant's home \\
\hline Lotta (F) & 21.11 .2016 & $34: 07$ & researcher's home \\
\hline Maria (F) & 2.10 .2016 & $61: 08$ & hotel lobby \\
\hline Marko (M) & 3.12 .2016 & $78: 31$ & researcher's home \\
\hline Niko (M) & 19.1 .2017 & $39: 30$ & via Skype \\
\hline Olli (M) & 4.9 .2016 & $38: 24$ & researcher's home \\
\hline Pasi (M) & 25.8 .2016 & $39: 18$ & researcher's home \\
\hline Riikka (F) & 5.11 .2016 & $45: 24$ & researcher's home \\
\hline Roni (M) & 22.12 .2016 & $41: 22$ & participant's home \\
\hline Samu (M) & 12.11 .2016 & $62: 14$ & participant's home \\
\hline Sanna (F) & 16.1 .2017 & $79: 56$ & via Skype \\
\hline Tuukka (M) & 13.10 .2016 & $63: 02$ & researcher's home \\
\hline
\end{tabular}




\section{Appendix 3: Step 3 of the thematic analysis (initial themes)}

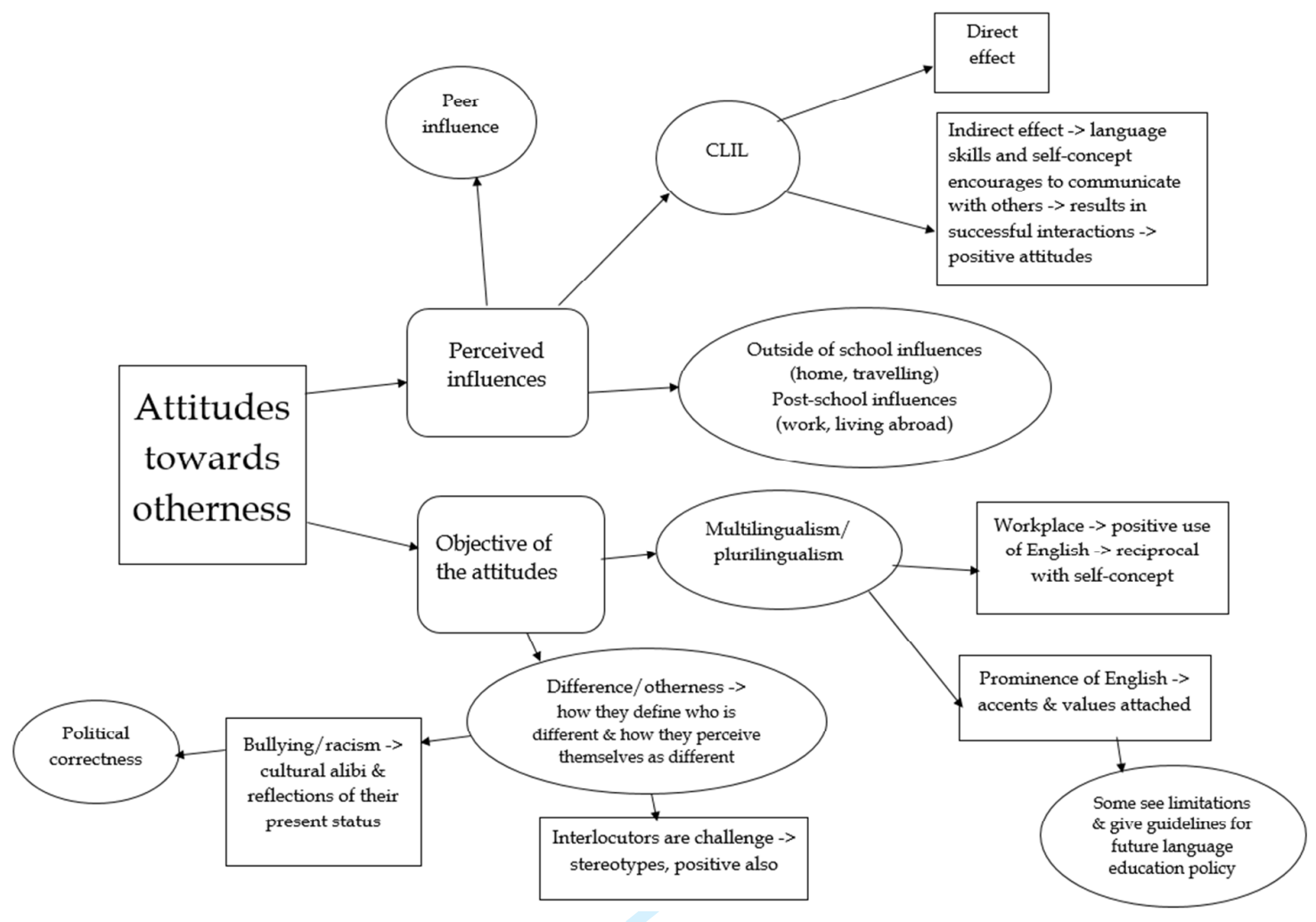


Appendix 4: Step 5 of the thematic analysis (final themes)

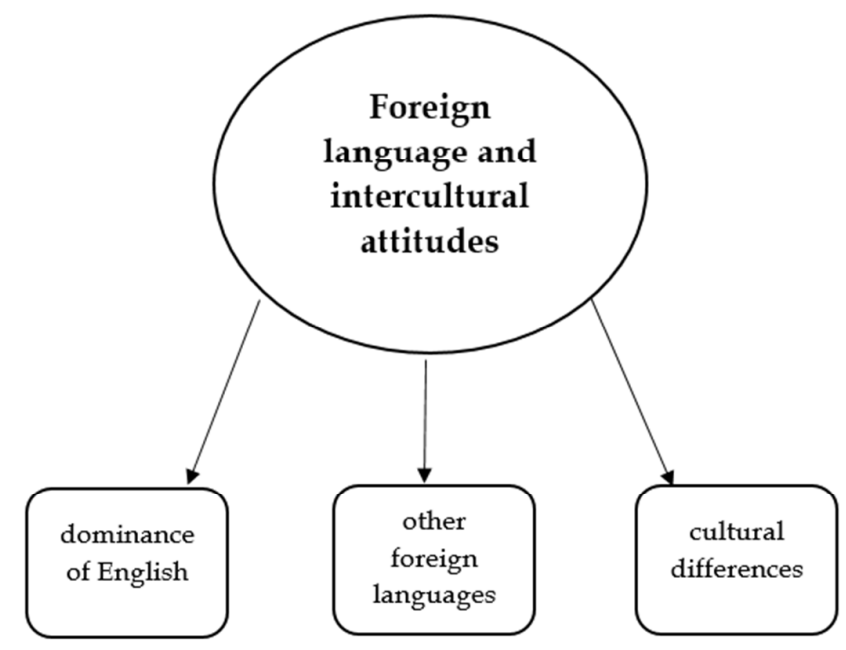




\section{Appendix 5: The quotes in the original language}

(1) Siellä [lukiossa] musta niinkun tuntu et se oli ehkä se niinkun tähän asti suurin hyöty.. siitä niinkun englantipainotteisesta [opetuksesta].. siellä niinkun tuntu siltä et se oli niinkun ehkä isoimmat erot niinkun muihin verrattuna.. ja et se oli niinkun tosi jotenkin helppoa ja eikä koskaan niinkun ahistanu puhua englantia. (Kalle)

(2) Vaikkei se sisältö oiskaan ihan timanttista niin jos sä osaat niinkun.. ilmaista itseäs hyvin englanniks niin sä vaikutat fiksummalta mitä sä ootkaan.. niin kyl mä veikkaan et osittain sen takia pääsin sinne [töihin].. et siellä [töissä] sai jonkinnäköstä arvostusta sen kautta että osas hyvin englantia. (Juho)

(3) No englanti on niin kansainvälinen kieli.. et se.. se on niinkun.. sillä pärjää joka paikassa kuitenkin aika lailla ja.. tai ainakin monessa paikassa ja se.. kuitenkin antaa sitten aika paljon vaihtoehtoja enemmän kun että vaikka ruotsin kielellä tai venäjän kielellä käytäis niitä asioita niin ne on kuitenkin vähän suppeemmat ne vaihtoehdot et siitä et mitä saa. (Kaapo)

(4) Tavallaan muita kieliä sitten periaatteessa ei tarvii jos englannin osaa.. mä en sillä lailla ymmärrä sitä logiikkaa joillakin jotka haluaa oppia useita kieliä just sen takia että niinkun ku englannilla periaatteessa pärjää lähes kaikkialla. (Tuukka)

(5) Jos se englanti ei olisi tuntunut siinä kohtaa niin vahvalta niin sitten se ehkä ois.. niinkun tavallaan sellasen toisen pitkän kielen alottaminen tuntunu niinkun.. voinu tulla isompi kynnys siihen. (Marko)

Joskus ehkä miettiny sitä et.. mulla oli seuraavat kielet sit sen jälkeen.. esimerkiks saksa oli aika vaikee alottaa et onks.. onks se että ei oo niinkun.. se on ollu liian helppoo se englanti ja sit et ei niinkun se seuraava kieli.. mä en tiiä onko.. onks täs mitään todellisuuspohjaa mut et ei oo niinkun joutunu opiskeleen kieltä muuta ku sit vasta myöhemmässä vaiheessa.. niin oon joskus ajatellu et se on ehkä hidastanu. (Niko)

$\mathrm{Ku}$ vertas siihen että ku englanti oli niin vahva ja se oli niin luontevaa niin ei sitten osannu lähtee opiskelemaan toista kieltä silleen niinkun pänttäämällä ja oikeesti taistelemalla. (Jonne)

Onhan se [CLIL-opetus] niinkun ehdottomasti myös niinkun tällasia pehmeitä arvoja.. suvaitsevaisuutta.. että on se kuitenkin niinkun mahdollistanu sen et tosiaan.. tosiaan ymmärtää erilaisia [ihmisiä].. muitakin kun suomalaisia. (Kimmo)

Voihan se olla et se vaikuttais sitten ettei ois niin kiinnostunu tollasista eri kulttuureista.. et et.. kyllä se varmaan ois niinkun ison osan.. iso osa pois elämästä että. (Annika)

Luulen et se niinkun lähtökohtasesti sit kun meitäkin oli.. meitä oli niinkun siinä peruskoulussa niinkun eri maissa asuneita ja sit muutenkin jotenkin ehkä tutustuttiin niihin kulttuureihin.. niin jotenkin se on.. mä luulen että jotenkin semmonen paljon avoimempi.. tai semmonen niinkun uusia asioita. (Jere)

(11) Mä olin niinkun opiskelija-aikoina olin vaihossa ja sit myös niinkun Suomeen tulevien vaihtareitten kanssa aika paljon tekemisisssä.. et se niinkun kielitaito mahdollisti sen et niitten kans tuli hyvin juttuun.. ja sit se ehkä niinkun avannu semmosen mielenkiinnon muita kulttuureita kohtaan.. tosiaan ku on kerran asunu ulkomailla niin se kynnys muuttaa töitten perässä on varmaankin niinkun sata kertaa pienempi.. et kyl tää niinkun kaikki liittyy toisiinsa ja mun mielestä se kielitaito on itelle niinkun mahdollistanu tän että ei oo 
niinkun tarttenu niinkun hävetä omaa kielitaitoo tai rajottaa itteensä keskusteluissa ulkomaalaisten kanssa. (Niko)

(12) Englannin kanssa se on vaan niinkun mahdollistanu tosi paljon muuta et.. opiskelupaikan ja sit ystävii muista maista ja.. ja työura niin kaikki on niinkun ollu helpompaa sen kielitaidon kautta.. tota voi olla et en asuis ulkomailla.. jotenkin niinkun ois varmaan tiukempi se yhteys suomalaisiin ja jotenkin vähän enemmän ehkä jopa niinkun semmonen suomikeskeisempi koko maailmankatsomus että.. nyt jotenkin ajatusmaailma on sitte taas päinvastanen et ei niinkun suomiasiat ihan kauheesti enää kiinnosta. (Niko)

(13) Pahimpia oli kiinalaiset ja joissain tapauksissa venäläiset.. kiinalaiset oli niinkun.. niitten kanssa oli todella vaikee tulla toimeen vaikka meilläkin niinkun kaikissa asioissa aina painotettiin sitä että on kulttuurieroja ja näin.. mut että kyllä ne on ihan omassa maailmassaan niinkun.. et jotenkin tuntu et välillä että ne.. se niitten niinkun maailmankuva on ihan.. aivan erilainen.. et ne ei niinkun.. ei niinkun ym.. ne ei ajattele samalla tavalla kun me.. siellä on niitä poikkeuksia niinkun.. usein ne on sitten semmosia jotka on asunu jossakin länsimaissa.. tai että.. mut et jotka niinkun on.. vaikee sanoo et jotka on tosi fiksuja.. et eihän ne muutkaan tyhmiä varmaan oo mutta tota.. niinkun että on.. on semmosia yksilöitä joiden kanssa on.. länsimaalaisen on helppo tulla toimeen.. et semmosiakin löytyy. (Juho) 
Table 1. The participants of the study and their CLIL experience.

\begin{tabular}{|c|c|c|c|c|c|c|c|c|c|c|}
\hline Name & $\begin{array}{l}\text { Pre- } \\
\text { school }\end{array}$ & $\begin{array}{l}1^{\text {st }} \\
\text { grade }\end{array}$ & $\begin{array}{l}2^{\text {nd }} \\
\text { grade }\end{array}$ & $\begin{array}{l}3^{\text {rd }} \\
\text { grade }\end{array}$ & $\begin{array}{l}4^{\text {th }} \\
\text { grade }\end{array}$ & $\begin{array}{l}5^{\text {th }} \\
\text { grade }\end{array}$ & $\begin{array}{l}6^{\text {th }} \\
\text { grade }\end{array}$ & $\begin{array}{l}7^{\text {th }} \\
\text { grade }\end{array}$ & $\begin{array}{l}8^{\text {th }} \\
\text { grade }\end{array}$ & $\begin{array}{l}9^{\text {th }} \\
\text { grade }\end{array}$ \\
\hline Anna $(\mathrm{F})^{3}$ & & & & & & & & & & \\
\hline Annika (F) & & & & & & & & & & \\
\hline Arttu (M) & & & & & & & & & & \\
\hline Eemeli (M) & & & & & & & & & & \\
\hline Emmi (F) & & & & & & & & & & \\
\hline Hanna $(F)$ & & & & & & & & & & \\
\hline Jere (M) & & & & & & & & & & \\
\hline Jonne (M) & & & & & & & & & & \\
\hline Juho (M) & & & & & & & & & & \\
\hline Jukka (M) & & & & & & & & & & \\
\hline Kaapo (M) & & & & & & & & & & \\
\hline Kalle (M) & & & & & & & & & & \\
\hline $\operatorname{Kimmo}(\mathrm{M})$ & & & & & & & & & & \\
\hline Lotta (F) & & & & & & & & & & \\
\hline Maria $(F)$ & & & & & & & & & & \\
\hline Marko (M) & & & & & & & & & & \\
\hline Niko (M) & & & & & & & & & & \\
\hline Olli (M) & & & & & & & & & & \\
\hline Pasi (M) & & & & & & & & & & \\
\hline Riikka (F) & & & & & & 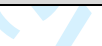 & & & & \\
\hline Roni (M) & & & & & & & & & & \\
\hline Samu (M) & & & & & & & & & & \\
\hline Sanna (F) & & & & & & & & & & \\
\hline Tuukka (M) & & & & & & & & & & \\
\hline
\end{tabular}

